\title{
The Spiritual Path of Pilgrimage Tourism for Sustainable Development: Case-Desa Astana- Cirebon, Indonesia
}

\author{
Hilwati Hindersah*, Ina Helena Agustina, Ivan Chofyan \\ Department of Urban and Regional Planning, Universitas Islam Bandung, Bandung 40116, Indonesia
}

Corresponding Author Email: hilwati@unisba.ac.id

https://doi.org/10.18280/ijsdp.160415

Received: 29 April 2021

Accepted: 10 July 2021

\section{Keywords:}

case-Astana-village-Cirebon, spiritualpath-pilgrimage-tourism

\begin{abstract}
The Cirebon region which is located in the province of West Java, Indonesia has valuable artifacts and sites as a source of knowledge. Conservation in this area has not been actualized yet, even though it has potential for pilgrimage tourism destinations. The purpose of this research is to describe the spiritual path of Cirebon pilgrimage tourism. The method used is a case study, this method is more operational to find out why and how the spiritual path of the Cirebon pilgrimage was formed. The findings of this study are the existence of a spiritual path that connects the cemetery locations and sites such as: Talun Keramat Cemetery is located in Cirebon Girang Village, Talun District, Syekh Magelung Sakti Site is located in Karangkendal Village, Kepetakan District, Nyi Mas Gandasari Tomb is located in Pangurang Village. Arjawinangun District and one that is very well known to foreign countries is Astana Sunan Gunung Jati in Astana Village, Gunungjati District. The results of the study provide direction for developing a spiritual path to become a Cirebon tourist destination package as well as regional conservation.
\end{abstract}

\section{INTRODUCTION}

Before becoming the Unitary State of the Republic of Indonesia, Indonesia was a country formed from various kingdoms. Artifacts of these kingdoms are still left today, one of which is the Sultanate in Cirebon. Cirebon is an area known as the Kingdom of Islam and the center of the spreading of Islam in West Java Island. Artifacts, sites and descendants of past sultanates still exist today. All of these are valuable assets for conservation programs, knowledge exploration and sustainable development, which have implications for improving the economy through the tourism sector.

Various impacts of tourism have been found, namely increasing foreign exchange earnings and increasing community assets and living standards those are positive impacts of ref. [1]. In addition to the prospects for generating income, tourism development can also lead to the preservation and revival of the socio-cultural heritage of its people [2]. Tourism is increasingly seen as a panacea, enhancing the economic viability of marginalized areas, stimulating social regeneration and improving living conditions. Public Countries that have great potential for natural and cultural wealth, need to be exploited for their tourism [3]. Tourism is a silver bullet for the local population, this sector appreciates economic, social and market benefits through increased income and job opportunities, encouraging business activities, improving infrastructure, preserving community culture.

Cultural tourism has recently been reaffirmed by the World Tourism Organization (WTO) as a major element of international tourism consumption, accounting for more than $39 \%$ of tourism arrivals. Main research trends include a shift from tangible heritage to intangible heritage, more attention to indigenous groups and other minorities and a geographic expansion in the scope of cultural tourism research [4]. Local culture is an accumulation of the traits and souls of local communities after developing in a long period of time in a certain geographic area, which is a standard means of differentiating one culture from another. Local culture can be divided into three basic categories: material, behavioral and spiritual culture [5]. The rich cultural treasures of the Cirebon region have become an asset for tourism consumption.

Development of tourism routes, stimulating opportunities for the development of small-scale indigenous tourism projects in less developed areas [3]. Research on the "Spiritual Route" has been carried out by Dayoub et al. [6] for the Case of the State of Syria. The research objective is for a sustainability strategy. The approach method is using Strengths, Weaknesses, Opportunities, Threats (SWOT) Analysis. The findings of this study indicate that the "Spiritual Route" has a multiplier effect on regional economic growth.

Astana Village research and tourism activities have not been widely explored. Research on the Spiritual Path for the Case of Astana Village Cirebon with the heritage potential of Cirebon has never been done before. Several studies have been conducted to identify the potential socio-economic conditions of Astana Village [7] and the tradition of bathing in a pitu well [8]. The spiritual path of pilgrimage tourism for the AstanaCirebon Village Case has a location connection with other pilgrimage tourism destinations. Tourists come from various regions and even countries (results from interviews with the officer of the tomb of Astana Sunan Gunung Jati). This potential requires international promotion and cooperation across regional boundaries (Cirebon City and Cirebon Regency). The conservation of tourist objects in both regions has conservation efforts and protection of Cirebon's past history through the case of Astana Village. To fill this gap, the 
distribution of sites and artifacts in the Cirebon area is tied together in a single spiritual route for pilgrimage tourism. This study aims to formulate a spiritual route for conservation development as well as for the economic development of the community. Beginning with literature review and description of methodology, it is followed by result and discussion of spiritual routes in Cirebon as conservation as well as spiritual path as innovation for local economic growth. Finally, the conclusion describes the findings which contribute to the originality of the Cirebon City and Regency conservation program through the spirituality route of pilgrimage tourism.

\section{LITERATURE REVIEW}

The global tourism industry has developed rapidly and has caused many social changes over the past 50 years [9]: The global trend of cultural tourism has attracted the attention of countless tourists [10]. Culture and tourism have always been closely related, but only in the last few decades the relationship between culture and tourism has been identified more explicitly as a specific form of consumption: cultural tourism [4].

The cultural tourism program reduces the spatiality of the tourism model which is concentrated in one place [11]. The elements of 'people-to-place ties' that can contribute to the sustainability of intangible cultural heritage, and how they contribute to the sustainability of heritage tourism. The bonds connecting individuals and meaningful places also attachments to places have received attention for the last decades. Place attachments, place identities and a sense of community can help us to understand better of how environmental spaces can encourage residents to work collectively to protect, conserve, develop their communities, and contribute to local planning processes [12]. Tourism researchers have focused their attention on understanding people who seek a nostalgic experience, and as a result, these ideas are placed in the emotional and spatial context of experience [13].

Cultural Routes not only provide creative activities and learning media, but they also maintain sustainable tourism [6]. In literature, the walking paths that is associated with religion values towards Islamic pilgrimage sites is pilgrimage tourism [14]. In contemporary literature, religious pilgrimages are treated as a subcategory of modern pilgrimage which includes religiously motivated trips to holy places which can consist of: a) elements of the natural environment such as mountains, rivers, caves, gardens or even animals; b) religious sites such as churches, temples, or places of worship; c) places for religious activities, rituals, or festivals. Religious tourism is one of the oldest forms of tourism, and represents a significant, growing, sector of the global tourism market. growing, and increasingly diverse [15]. Common examples of religious travel and tourism include pilgrimages, retreats, conferences, seminars and festivals. Religious tourism includes 'a variety of spiritual sites and related services, which are visited for both secular and religious reasons. However, religious tourism is not only a call for spirituality, but also a major economic driver [16]. Moreover, pilgrimage tourism could be important instrument for sustainability [17].

Niezgoda and Bartosik found that the type of tourism can be built on the basis of economic, geographic, demographic, psychological and socio-cultural criteria [18]. Dolnicar asserts that psychographic or sociodemographic behavioral variables can be used to segment cultural tourism [19]. Dolnicar also proposed that the segmentation criteria based on tourist characteristics could be separated into four groups: sociodemographic; geographical; behavior; and psychographics [20].

Route-based travel arises from marketing cultural artifacts as tourism commodities from the characteristics and trends of contemporary use of pilgrimage routes. Tourists visiting heritage sites are guided by a constructed itinerary shaped by a coherent spatial structure [21]. Tourism activities are usually group-oriented, and the preferences and goals of group members, it is necessary to design personalized tourist routes for heterogeneous tour groups [22].

The development of tourist routes has become famous in recent years, the purpose of tourist routes is to tie between tourist destination objects and to improve the economy of the poor in the areas that these routes pass through [23]. Pilgrimage tourism routes are part of heritage conservation. Although notion of heritage does not present in discussion of sustainable development [24], conservation activities are necessary. It sharpened in various sectors of regional development policies. Conservation practices and tourism development are resolved by reviewing the master plan and increasing cooperation among stakeholders [25]. Local tourism stakeholders provide the basis for a sustainable tourism development process [26]. Based on Pierre Bourdieu's theory of cultural change, proposes a conceptual framework to explain the relationship between political power and tourism development [5].

The Cirebon region is an area full of cultural artifacts from the past. Research on the spiritual path of pilgrimage tourism provides conservation efforts on these past cultures. Research on the spiritual path of Cirebon pilgrimage tourism has not been carried out although the potential of this research will have implications for knowledge exploration, conservation and sustainable development of the Cirebon region and even Indonesia. Pilgrimage tourism with a great opportunity to grow [27] will make the region grow sustainable.

\section{METHODOLOGY}

\subsection{Study context}

Cirebon is an area located in the West Java Province of the Republic of Indonesia. Cirebon is connected by a toll road network from the capital city of the Republic of Indonesia, Jakarta. The scope of the research area includes the administrative areas of Cirebon City and Cirebon Regency. Geographically, Cirebon City is in the position $108^{\circ} 33 \mathrm{E}$ and $6^{\circ}$ 41. Meanwhile Cirebon Regency is in the position of $108^{\circ} 40^{\prime}-108^{\circ} 48^{\prime}$ East Longitude and $6^{\circ} 30^{\prime}-7^{\circ} 00^{\prime}$ South Latitude. These two regions are located next to each other. The three palaces (Keraton Kasepuhan, Keraton Kanoman and Keraton Kacirebonan) are located in Cirebon City but other palace sites / artifacts are outside the city of Cirebon, one of which is the grave of his ancestors in Astana Village, Gunung Jati District, Cirebon Regency. This study covers both areas. The position of the research location can be seen in the picture (Figure 1 shows the position in West Java and Figure 2 shows Cities and Regencies that are the orientation of study locations). 


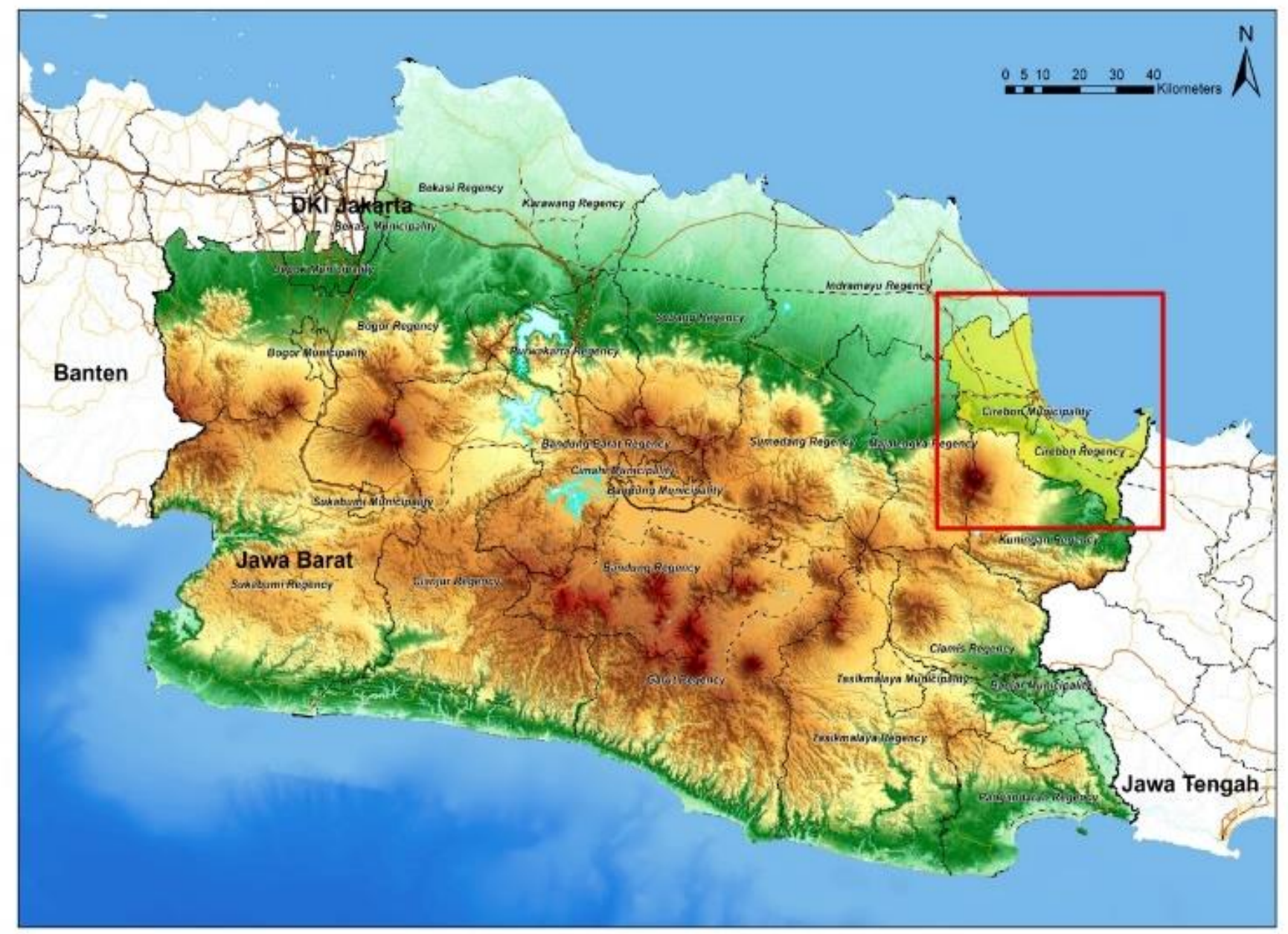

Figure 1. Position of research sites in west java

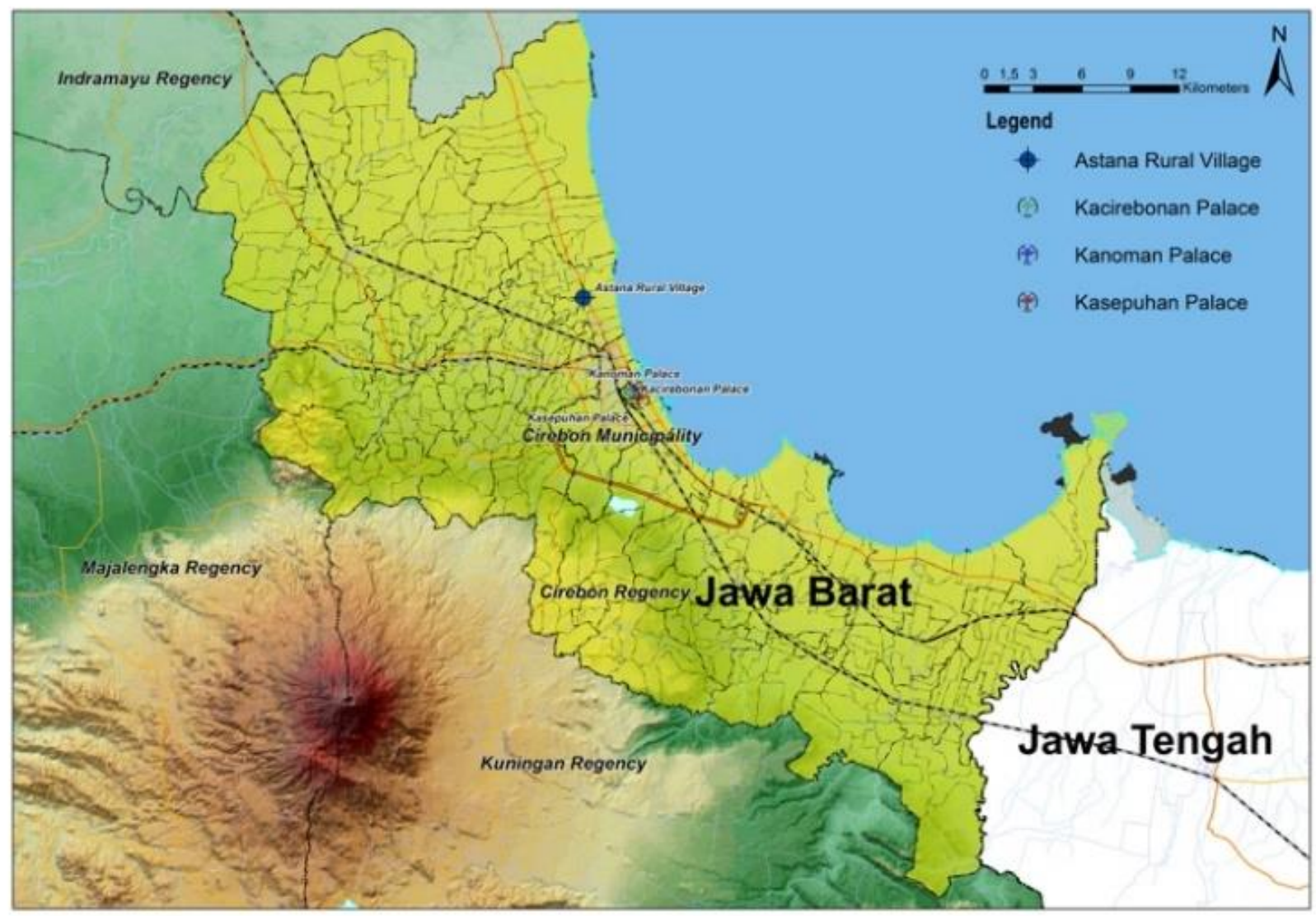

Figure 2. Position of Cirebon city and Cirebon regency 


\subsection{Data collection procedure}

The researcher has been conducting research in this area since 2010. The data collected has been carried out since that year. New data collection adapted to the focus of ongoing research. Data collection was carried out by means of surveys and observations. The survey for primary data collection in the form of field information was obtained by means of structured interviews with courtiers (workers) in the palace, bekel (workers at the graves) and pilgrims. The interview technique is snow balls. The interview processes are recorded and controlled using interview protocol. The protocol is made in a sheet form which contains not only questions list but also spaces for writing notes related to responses by the interviewees. The spaces for notes are also used to briefly summarize the respondent responses. These summaries were then to be extracted. The protocol sheet also includes information regarding time, place and position of the interviewee.

Meanwhile, field visualization is recorded through photographic tools. The field observation process was carried out for three days in February 2021. The observation process was carried out from 9.00 - 16.00 hours. The observation process is assisted by a team of surveyors. The map of the study area was obtained from studies conducted by researchers from 2010-2019. Furthermore, it is redrawed from the interpretation of the interview data.

\subsection{Data analysis}

The analytical method used is by using the case study method. Case Study Research is research that can explain "How" and "Why" [28-30]. Based on these references, the analysis carried out is to be able to construct these questions. The research case on the spiritual path of Astana Village was carried out in the following steps: (1) The field data from the interviews were sorted, (2) The data was codified, (3) The data were grouped, (4) The data were interpreted to answer the question of how and why the spiritual journey was carried out by pilgrim tourists.

\section{RESULT AND DISCUSSION}

\subsection{Spiritual routes in Cirebon as conservation}

This study aims to formulate a spiritual route and describe the sustainability of spiritual tourism in Cirebon. The findings of the study resulted in the formulation of a spiritual tourism route to explore the locations of the graves. How to reach tourist sites is done in various ways. The reasons for spiritual tourism are revealed by tourists. The description of the phenomenon of affix activities in spiritual tourism activities is also found in the field. The findings of the study contribute to the sustainability policy of tourism in Cirebon.

The study findings indicate that the spiritual route consists of several destination locations. Objects of spiritual destinations in Cirebon are tombs or sites of powerful people associated with the establishment of the kingdom and the spread of Islam in Cirebon. Tourists call it a pilgrimage tour. The tourist destination object that is the destination is the Talun Keramat Cemetery located in Cirebon Girang Village,
Talun District, the Syekh Magelung Sakti site is located in Karangkendal Village, Kepetakan District, Nyi Mas Gandasari Tomb is located in Pangurang Village, Arjawinangun District and the most famous to foreign countries is Astana Sunan Gunung Jati in Astana Village, Gunungjati District. From these objects, the Tombs of Sunan Gunung Jati and the palaces are the main orientations for tourists to visit. The location of the destination has a history of places and humans who have played a role in spreading Islam. Further, it can be seen in Figure 3.

The movement pattern of tourists to the location is carried out using various modes of transportation. The mode of transportation is chosen by tourists who come from various regions in Indonesia and abroad (such as Malaysia). Tourists reach tourist sites in various ways, including by foot. Some pilgrims still believe that by walking they will get more blessings, this method is compatible with findings from pilgrimage tours carried out by tourists at other pilgrimage sites [14]. There are also pilgrims who come with their entourage by renting a bus, generally they come from outside Cirebon. The pattern of movement will lead to sacred grave locations, but the main objectives are the palaces and the Astana Village, namely the Sunan Gunung Jati tomb complex.

The study findings indicate that the spiritual tourism route was formed due to Cirebon's historical past. Spirituality is formed from the teachings of the Islamic religion that were spread by Sunan Gunung Jati, his friends and descendants. The name Sunan Gunung Jati as the first spreader of Islam in West Java Island has become an attraction for spiritual tourism [31]. Sunan Gunung Jati as a member of the walisanga (nine guardians) characterized a holy man. The sanctity of Sunan Gunung Jati is still believed by tourists. The sacred human energy of Sunan Gunung Jati is believed to bring blessings to human life (interview with tourists). This phenomenon shows the same indication as the tourism literature that there is a bond with the place that tourists feel, or the emotional and spatial context of experience [13].

The ritual procession in Astana Village is carried out by visiting 7 wells, which the water is considered to bring blessings, then carrying out a tahlil procession (Praying and reciting the holy verses of al-Quran at the Sunan Gunung Jati Tomb complex, see in Figure 4. These findings indicate an understanding of nostalgia, as a contributing factor to tourism [13].

Another reason for the formation of spiritual tourism is the existence of the descendants of Sunan Gunung Jati, namely the Cirebon palaces. The Cirebon Palace and its descendants are the guardians of the spiritual tradition of Sunan Gunung Jati. The spiritual tradition follows the time of the Javanese calendar or the Islamic calendar. The spiritual tradition that is the main attraction is the tradition in the month of the birth of the Prophet Muhammad, namely the month of Mulud (Javanese calendar) or Rabiul Awal (Islamic calendar). But it is possible that tourists will still attend at other times, such as the time before the month of Ramadan according to the Islamic calendar, tourists doing pilgrimage tours / spiritual tours at the Sunan Gunung Jati Tomb (can be seen in Figure 5 below). Spiritual tourism carried out by tourists has the same tendency as the Islamic religious rituals. This condition shows that the Islamic ritual that was sent down by Sunan Gunung Jati is still maintained. 


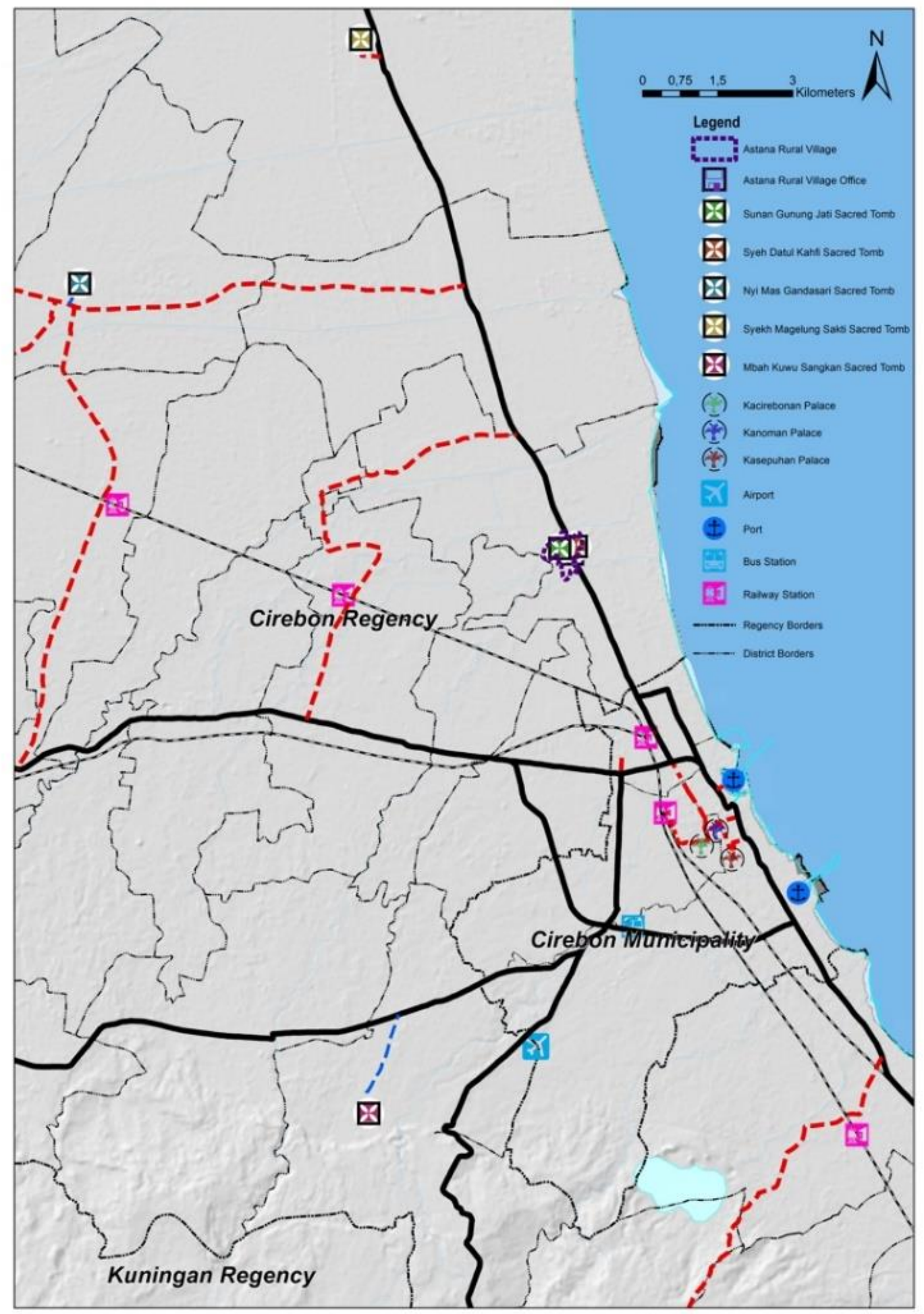

Figure 3. Location of spiritual destination objects in Cirebon

\subsection{Spiritual path as innovation for local economic growth}

Astana Village is a tomb complex for Sunan Gunung Jati and his descendants or the kings and their families of the Cirebon kingdom. The tomb is guarded by tomb officers called jeneng, bekel and kemit. They are appointed by the kings of the Kasepuhan and Kanoman Palace. This tomb complex is never empty of visits by pilgrim tourists, even tourists get access to 24-hour service by tomb officers. Tomb officers can play a role in serving tourists to perform rituals such as dhikr and performing tahlil at these graves.

High tourist visits to the Astana Village complex resulted in the growth of the trade sector around the tomb complex being more dominant than other spiritual tourism objects. Stalls that provide tourist needs from water containers, potpourri, Cirebon special food and drinks, clothes to bathroom rental places for tourists. These stalls serve 24 hours, because tourists visit all the time. These stalls grew sporadically in the tomb complex, even traders thronged the entrance so that it looked like a market. This means that spiritual tourism fosters people's creativity to sell around the graves (see Figure 6 and Figure 7). This phenomenon supports the statements of ref. [6] that spiritual tourism has a multiplier effect on economic growth. 


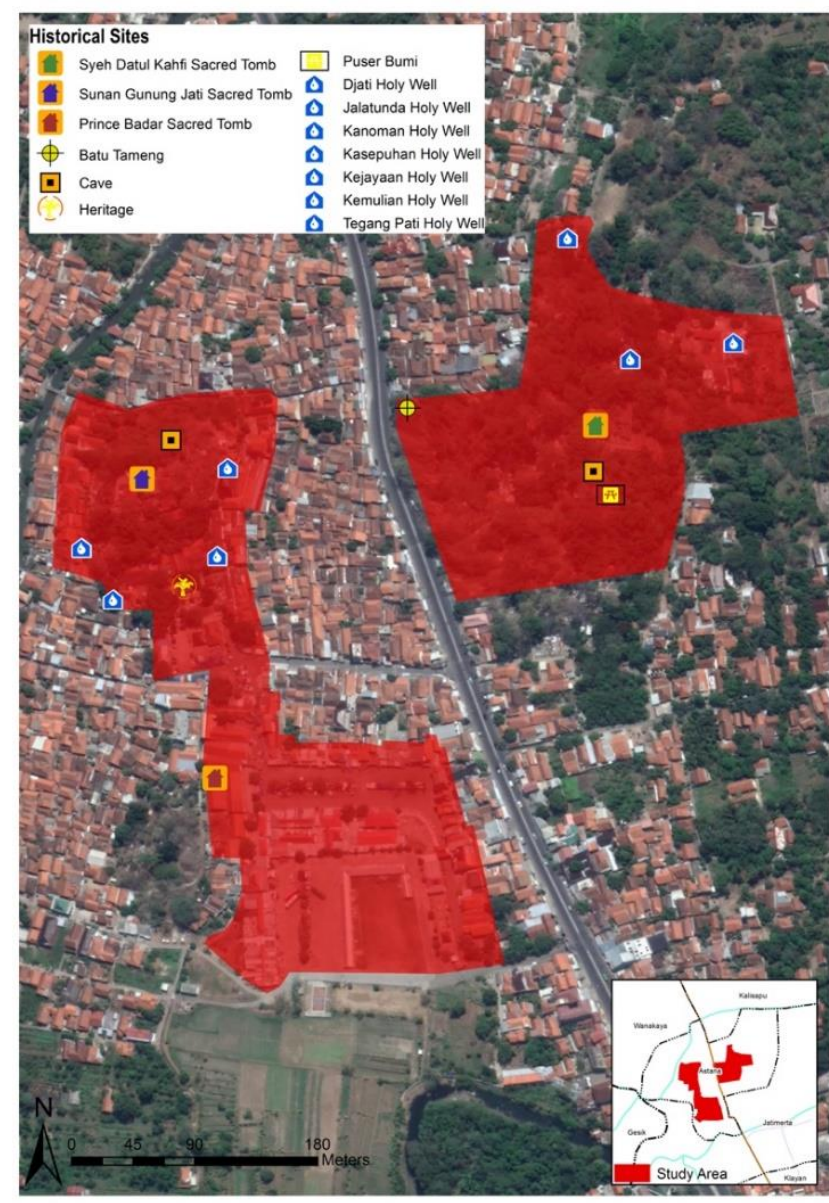

Figure 4. Position of Wells and Tomb Complex of Sunan Gunung Jati in Astana Village

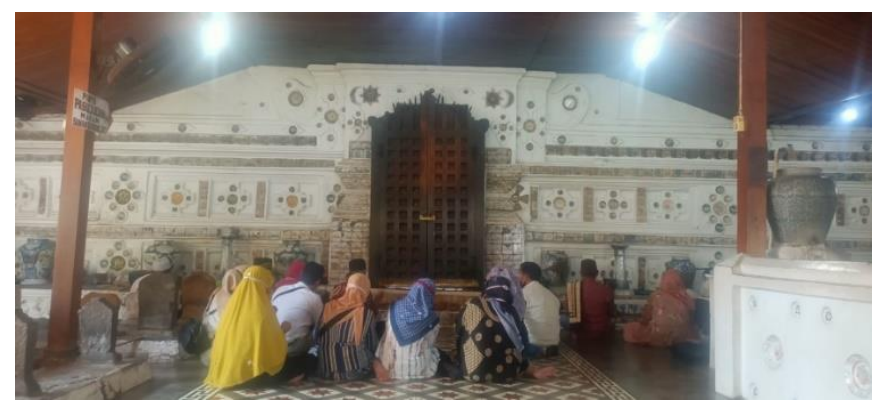

Figure 5. Pilgrimage Tour for the Month of Shaban $1442 \mathrm{H}$

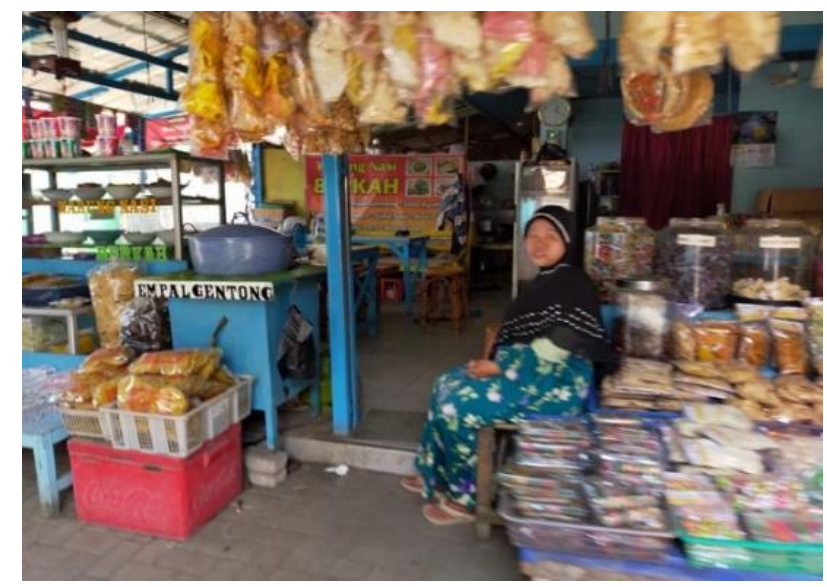

Figure 6. A stall selling special food and drinks in the Sunan Gunung Jati Tomb Complex, Astana Village

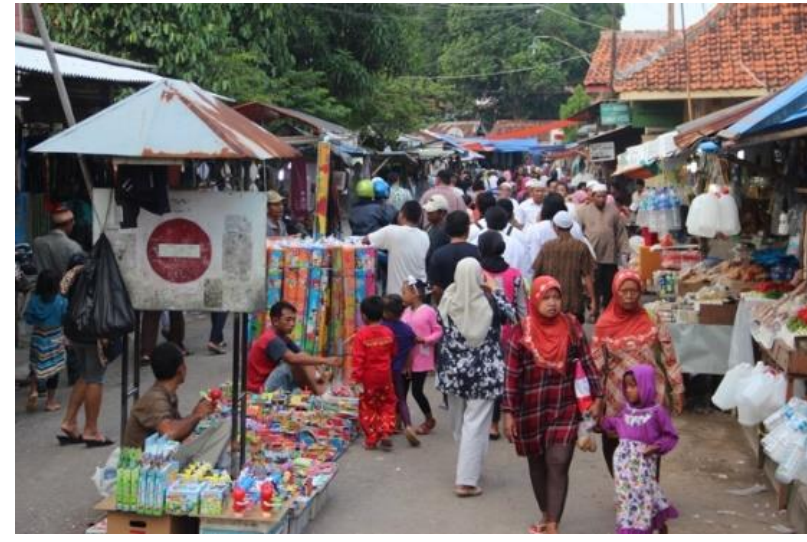

Figure 7. Traders crowding the street to the Sunan Gunung Jati Tomb Complex, Astana Village

The growth of trade in spiritual tourism objects indicates the local economic growth of the surrounding community. Cultural Routes not only provide creative activities and learning media, but they also maintain sustainable tourism [6]. Niezgoda and Bartosik found that the type of tourism can be built on the basis of economic, geographic, demographic, psychological and socio-cultural criteria [18]. Spiritual tourism in Cirebon can grow because of these criteria, it is even proven to give an indication of the growth of the local economy of the surrounding community. However, the findings of this study are not actualized in the Cirebon tourism planning document, both spatial planning documents and spiritual path planning which are integrated into spatial planning. As a result, these tourist objects only grow sporadically and are not comprehensively integrated with one another.

\section{CONCLUSION}

The findings of the study show that the spiritual pathway in Cirebon is oriented towards pilgrimage tours of tombs and sites such as: Talun Keramat Cemetery is located in Cirebon Girang Village, Talun District, Syekh Magelung Sakti Site is located in Karangkendal Village, Kepetakan District, Nyi Mas Gandasari Cemetery is located in Pangurang Village, Arjawinangun District and which is very famous to foreign countries is Astana Sunan Gunung Jati in Astana Village, Gunungjati District. Development of a spiritual route for the Cirebon pilgrimage tour gives an indication of a spiritual path that plays a role in the conservation of pilgrimage tourism in the Cirebon region. Including his palaces as descendants of the holy man Sunan Gunung Jati. The implication is that conservation in Cirebon must be comprehensive in a crossregional spatial unity.

Other findings, related to the concentration of local economic growth that is very evident in the Astana Village Tomb Complex compared to other locations, have implications for the local economic growth of the community. Local economic growth must be followed up by expanding tourist attractiveness in other tourist objects, so that local economic growth will also spread to the surrounding regions. In addition, program for strengthening local economic capacity could be facilitated by local government for supporting management of pilgrimage tourism activities and maintaining sustainability of local cultural production.

The role of the government as a facilitator, needs to follow 
up and mediate for conservation and local economic growth. Persuasive mediation with the palace needs to be built intensively. The palace party needs to collaborate with the local government in the realization of Cirebon spiritual tourism so that it is actualized in spatial planning documents and other policies. Persuasive collaboration needs to be built to follow up on the strategic value for economic growth from the development of spiritual route tourism in Cirebon.

\section{ACKNOWLEDGEMENT}

The authors would like to thank the Bandung Islamic University Research and Service Institute for funding this research.

\section{REFERENCES}

[1] Blapp, M., Mitas, O. (2017). Creative tourism in Balinese rural communities. Current Issues in Tourism, 21(11): $1285-1311$.

https://doi.org/10.1080/13683500.2017.1358701

[2] Ahmad, A. (2012). The constraints of tourism development for a cultural heritage destination: The case of Kampong Ayer (Water Village) in Brunei Darussalam. Tourism Management Perspectives, 8: 106-113. https://doi.org/10.1016/j.tmp.2013.09.002

[3] Briedenhann, J., Wickens, E. (2004). Tourism routes as a tool for the economic development of rural areasvibrant hope or impossible dream? Tourism Management, 25(1): 71-79. https://doi.org/10.1016/S02615177(03)00063-3

[4] Richards, G. (2018). Cultural tourism: A review of recent research and trends. Journal of Hospitality and Tourism Management, 36:

$12-21$ https://doi.org/10.1016/j.jhtm.2018.03.005

[5] Liang, J.Y., Chan, C.S. (2018). Local cultural vicissitudes in regional tourism development: A case of Zhuhai. Tourism Management Perspectives, 25: 80-92. https://doi.org/10.1016/j.tmp.2017.11.016

[6] Dayoub, B., Yang, P., Dayoub, A., Omran, S., Li, H. (2020). The role of cultural routes in sustainable tourism development: A case study of Syria's spiritual route. International Journal of Sustainable Development and Planning, 15(6): 865-874. https://doi.org/10.18280/ijsdp.150610

[7] Agustina, I.H., Ekasari, A.M. (2017). Studi of Cultural Heritage in Astana Village Cirebon District. Proceeding the 8 Rural Research and Planning Group International Conference, pp. 264-272.

[8] Amaliyah, M.A. (2012). Pandangan Masyarakat Cirebon Terhadap Tradisi Mandi Sumur Pitu Di Desa Astana Gunung Jati. Bachelor Thesis, Iain Syekh Nurjati Cirebon.

[9] Sun, J., Zhang, S., Jie, M. (2019). Revisiting the impacts of tourism from the perspective of social space production: an ethnological study of the Muslim community in Sanya, Hainan Province, China, Current Issues in Tourism, 23(15): 1845-1863. https://doi.org/10.1080/13683500.2019.1653266

[10] Chang, L., Liu, W. (2009). Temple fairs in Taiwan: Environmental strategies and competitive advantage for cultural tourism. Tourism Management, 30(3): 900-904. https://doi.org/10.1016/j.tourman.2008.12.002

[11] Guedes, A.S., Jiménez, M.I.M. (2015). Spatial patterns of cultural tourism in Portugal. Tourism Management Perspectives, 16 https://doi.org/10.1016/j.tmp.2015.07.010

107-115.

12] Tan, S.K., Tan, S.H., Kok, Y.S., Choon, S.W. (2018). Sense of place and sustainability of intangible cultural heritage-The case of George Town and Melaka. Tourism Management, 67: 376-387. https://doi.org/10.1016/j.tourman.2018.02.012

[13] Christou, P.A. (2018). Tourism experiences as the remedy to nostalgia: conceptualizing the nostalgia and tourism nexus. Current Issues in Tourism, 23(5): 612625. https://doi.org/10.1080/13683500.2018.1548582

[14] Salma, U., Husein, M. (2018). A phenomenological study of Arbaeen foot pilgrimage in Iraq. Tourism Management Perspectives, 26: 9-19. https://doi.org/10.1016/j.tmp.2017.11.015

[15] Sharpley, R. (2009). Tourism, religion and spirituality. In T. Jamal, \& M. Robinson (Eds.). The SAGE handbook of tourism studies. London: Sage Publications Ltd. pp. 237-253.

[16] Iliev, D. (2020). The evolution of religious tourism: Concept, segmentation and development of new identities. Journal of Hospitality and Tourism Management, 45: 131-140. https://doi.org/10.1016/j.jhtm.2020.07.012

[17] Handriana, T., Yulianti, P., Kurniawati, M. (2019). Exploration of pilgrimage tourism in Indonesia. Journal of Islamic Marketing, 11(3): 783-795. https://doi.org/10.1108/JIMA-10-2018-0188

[18] Niezgoda, A., Bartosik, M. (2016). Changes and Challenges in The Modern Word Economy. Wydawnictwo Uniwersytetu Ekonomicznego w Poznaniu.

[19] Dolnicar, S. (2007). Management learning exercise and trainer's note for market segmentation in tourism. International Journal of Culture, Tourism and Hospitality Research, 1(4): 289-295. https://doi.org/10.1108/17506180710824172

[20] Castañeda, J.A., Vena-Oya, J., Rodríguez-Molina, M., Martínez-Suárez, R. (2019). Analysis of domestic cultural tourism spend by segment in the city of $\mathrm{T}$ Granada: An observational data approach. Tourism Management Perspectives, 29: 18-30.

[21] Mohamed, A.M.R.M., Samarghandi, S., Samir, H., Mohammed, M.F.M. (2020). The Role of Placemaking Approach in Revitalising AL-ULA Heritage Site: Linkage and Access as Key Factors. International Journal of Sustainable Development and Planning, 15(6): 921926. https://doi.org/10.18280/ijsdp.150616

[22] Zhenga, W., Liao, Z. (2019). Using a heuristic approach to design personalized tour routes for $\mathrm{T}$ heterogeneous tourist groups. Tourism Management, 72(3): 313-325. https://doi.org/10.1016/j.tourman.2018.12.013

[23] Meyer, D. (2004). Key issues for the development of tourism routes and gateways and their potential for ProPoor Tourism. https://www.researchgate.net/publication/242371864, accessed on March.18, 2021.

[24] Sirirat, P. (2019). Spiritual tourism as a tool for sustainability: A case study of Nakhon Phanom Province, Thailand. International Journal of Religious Tourism and Pilgrimage, $\quad 7(3)$ : $\quad$ Article 9. 
https://doi.org/10.21427/9nyd-w868

[25] Sirisrisak, T. (2013). Conservation of Bangkok old town. Habitat International, 33(4): 405-411. https://doi.org/10.1016/j.habitatint.2008.12.002

[26] Shafieisabet, N., Haratifard, S. (2020). The empowerment of local tourism stakeholders and their perceived environmental effects for participation in sustainable development of tourism. Journal of Hospitality and Tourism Management, 45: 486-498. https://doi.org/10.1016/j.jhtm.2020.10.007

[27] Zhu, H., Zhang, J., Yu, X., Hu, F. (2019). Sustainable tourism development strategies and practices of world heritage sites in China: A case study of Mt. Huangshan. International Journal of Sustainable Development and Planning, 14(4): 297-306. https://doi.org/10.2495/SDP-
V14-N4-297-306

[28] Eisenhardt, K.M. (1989). Building theories from case study research. The Academy of Management Review, 14(4): 532-550. https://doi.org/10.2307/258557

[29] Yin, R.K. (2009). Case Study Research: Design and Methods (4th Ed.). Thousand Oaks, CA: Sage.

[30] Nur'ain, R.D. (2020). Penerapan Metode Studi Kasus Yin Dalam Penelitian Arsitektur Dan Perilaku. Informasi dan Ekspose Hasil Riset Teknik Sipil dan Arsitektur, 16(1): 92-104. https://doi.org/10.21831/inersia.v16i1.31319

[31] Agustina, I.H., Djunaedi, A., Sudaryono, Suryo, D. (2016). Spatial constructs of spiritual consciousness: The case of Keraton Kasepuhan in Cirebon, Indonesia. ISVS E-Journal, 4(2):16-28. 